\title{
Perancangan Self-Assesment untuk Audit Internal ISO 9001:2015 dengan Metode Baldrige Scoring pada PT Alam Jaya Seafood
}

\author{
Xena Hillary ${ }^{1}$, Aditia Karuniawan ${ }^{2}$, Jani Rahardjo ${ }^{3 *}$ \\ 1,2,3Program Studi Teknik Industri, Universitas Kristen Petra, Surabaya, Indonesia \\ ( ${ }^{*}$ jani@petra.ac.id)
}

\begin{abstract}
Abstrak - Dalam menghadapi pasar internasional, mutu merupakan salah satu perhatian demi keberlangsungan bisnis pada suatu perusahaan. PT Alam Jaya Seafood memiliki fokus pada kegiatan ekspor dengan target pemasaran utama yaitu pasar Eropa dan Amerika sehingga jaminan mutu seperti sertifikasi ISO 9001:2015 merupakan hal yang penting untuk didapatkan. Saat ini, PT Alam Jaya Seafood sudah memiliki sertifikasi HACCP namun belum mendapatkan sertifikasi ISO 9001:2015. Penerapan dan pemenuhan persyaratan ISO mewajibkan adanya pelaksanaan Audit Internal. Salah satu metode alternatif untuk melakukan audit internal adalah dengan melakukan self-assessment. Self-assessment dapat dilakukan secara mandiri oleh perusahaan tanpa auditor dari luar sehingga lebih murah dan memakan waktu yang lebih singkat. Oleh sebab itu, penelitian dirancang dengan sistem penilaian audit internal secara mandiri atau self-assessment dengan menggunakan metode Baldrige Scoring. Hasil penelitian yaitu rancangan self-assessment yang meliputi rancangan pertanyaan dan degradasi penilaian yang dapat membantu PT Alam Jaya Seafood untuk mendapatkan sertifikasi ISO 9001:2015. Hasil dari Self Assesment tersebut diharapkan dapat digunakan sebagai dasar untuk melakukan peningkatan dan perbaikan pada sistem manajemen mutu di PT Alam Jaya Seafood sehingga dapat membantu PT Alam Jaya Seafood dalam menentukan langkah-langkah yang harus dilakukan dalam perbaikan sesuai dengan penilaian Baldrige Scoring.
\end{abstract}

Kata kunci: audit internal; Scoring; ISO 9001:2015; self-assessment

\section{PENDAHULUAN}

Perkembangan teknologi dan pertumbuhan ekonomi menimbulkan munculnya persaingan antar perusahaan dalam dunia bisnis. Setiap perusahaan berusaha untuk dapat menghasilkan produk dengan kualitas yang baik agar dapat diterima dan memberikan kepuasan bagi konsumen. Hal tersebut mendorong berbagai perusahaan untuk melakukan peningkatan mutu produk yang diproduksi. Berbagai perusahaan mulai melakukan perencanaan untuk melakukan perbaikan dan peningkatan pada sistem manajemen kualitas agar dapat memberikan jaminan terhadap keberlangsungan bisnis pada suatu perusahaan dan jaminan terhadap produk yang dihasilkan oleh suatu perusahaan mengingat semakin ketat dan meningkatnya persaingan antar perusahaan.

PT Alam Jaya Seafood merupakan perusahaan eksportir dan pengolah makanan laut beku terkemuka di Indonesia. PT Alam Jaya Seafood memiliki fokus pada kegiatan ekspor dengan target pemasaran utama yaitu pasar Eropa dan Amerika. Oleh karena itu, sertifikasi untuk produk dan perusahaan perlu diperhatikan agar dapat menembus pasar Internasional, khususnya penjaminan mutu dari produk yang akan di ekspor. Sertifikasi internasional yang penting untuk diterapkan adalah sertifikasi ISO 9001:2015.

Sertifikasi ISO 9001:2015 merupakan sertifikasi sistem penjaminan mutu terbaru yang diakui di tingkat internasional. Sertifikasi ini membantu untuk mendapatkan kepercayaan dari konsumen dan mendapatkan pangsa pasar yang lebih luas. Saat ini PT Alam Jaya Seafood sudah memiliki sertifikasi HACCP dan belum mendapatkan sertifikasi ISO 9001:2015. Sertifikasi HACCP hanya mencakup analisa risiko pada teknis kerja saja, sehingga belum mencakup ke sistem manajemen kualitas secara global. Penerapan ISO 9001: 2015 sudah dilakukan pada penelitian sebelumnya, namun penelitian tersebut hanya sebatas perancangan pemenuhan dokumen - dokumen kebutuhan sertifikasi ISO 9001:2015, penyuluhan dan penerapan klausul-klausul ISO 9001:2015 tetapi belum ada Audit Internal sebagai persyaratan wajib ISO 9001:2015. Audit internal harus dilaksanakan pada sebuah organisasi untuk memberikan informasi apakah sistem penjaminan mutu sesuai dengan persyaratan organisasi dan sesuai dengan persyaratan standar ISO 9001:2015. Audit internal dapat dilakukan dengan cara alternatif yaitu audit mandiri atau self-assessment. Self-assessment dilakukan oleh perusahaan secara mandiri yang kemudian hasil dari self-assessment akan divalidasi oleh auditor yang dipilih oleh perusahaan. Audit internal umumnya dilakukan secara manual oleh pihak eksternal, namun apabila dilakukan secara manual akan membutuhkan waktu yang lama dan biaya tinggi. Hal tersebut dapat diatasi 
dengan melakukan self assessment dikarenakan self assesment merupakan penilaian yang dilakukan oleh perusahaan sendiri sehingga mampu menghemat waktu dan biaya. Self-assessment dapat dilakukan dengan metode Baldrige Scoring. Oleh sebab itu, penelitian ini dilakukan untuk merancang pertanyaan dan penilaian yang diperlukan untuk melakukan audit mandiri atau self assessment di PT Alam Jaya Seafood dengan menggunakan metode Baldrige Scoring. Dari hasil dari self Assesment tersebut diharapkan dapat digunakan sebagai dasar untuk melakukan peningkatan dan perbaikan pada sistem manajemen mutu di PT Alam Jaya Seafood sehingga dapat membantu PT Alam Jaya Seafood dalam menentukan langkah-langkah yang harus dilakukan dalam perbaikan sesuai dengan penilaian Baldrige Scoring. Dengan adanya ISO 9001:2015 di PT Alam Jaya Seafood diharapkan mampu memberikan jaminan mutu terhadap produk PT Alam Jaya Seafood sehingga dapat memberikan dan meningkatkan kepercayaan dan kepuasan bagi konsumen.

\section{STUDI LITERATUR}

\section{A. Mutu dan Sistem Manajemen Mutu}

Mutu adalah kecocokan ciri, kriteria atau karakteristik dari suatu produk atau jasa untuk memenuhi kebutuhan, harapan dan juga kepuasan konsumen. Menurut (Al-Qahtani et al., 2015) Sistem Manajemen Mutu adalah suatu konsep dan strategi yang digunakan suatu perusahaan untuk dapat memberikan kualitas layanan yang baik kepada konsumen melalui pencapaian kerja sama antar anggota perusahaan (dalam Eric, 2020, p.05). Sistem manajemen mutu bertujuan untuk menjamin kesesuaian sebuah proses atau produk terhadap kebutuhan, spesifikasi atau kriteria persyaratan yang telah ditentukan oleh pelanggan atau sebuah organisasi. Terdapat beberapa prinsip dalam sistem manajemen mutu (Cognoscenti, 2015) yaitu fokus kepada pelanggan, kepemimpinan, keterlibatan orang, pendekatan proses, peningkatan, pengambilan keputusan berbasis bukti, dan manajemen hubungan (dalam Nasikin, 2019, p.04)

\section{B. ISO 9001:2015}

ISO 9001 (Dentch, 2016) adalah salah satu standar sistem manajemen mutu yang berisikan persyaratan dan ketentuan yang harus dipenuhi oleh suatu organisasi atau perusahaan (dalam Kurniawan,2018, p.03). ISO 9001 merupakan sertifikasi tingkat internasional yang berorientasi pada standar manajemen mutu dan layanan pelanggan yang diadopsi oleh International Organization for Standardization (ISO) pada tahun 2000. ISO 9001:2015 adalah sistem standar manajemen mutu terbaru yang telah direvisi pada tahun 2015. ISO 9001:2015 dirancang untuk membantu organisasi dalam memastikan bahwa organisasi tersebut dapat memenuhi kebutuhan pelanggan dan stakeholdernya serta dapat memenuhi perundangan, hukum dan peraturan yang berlaku terkait dengan produk atau jasa yang ditawarkan. Adapun tujuan dan manfaat penerapan ISO 9001:2015 adalah sebagai berikut. (Pengertian ISO 9001:2015, 2020).

- Untuk mengatur sistem administrasi dan dokumen dalam perusahaan

- Untuk mengelola risiko yang dapat muncul dari sebuah perusahaan

- Untuk membangun sistem dasar dalam perusahaan dari sistem yang berhubungan dengan manusia, hingga mencakup proses produksi

- Untuk memastikan setiap proses dan tahapan yang dilakukan sudah sesuai dengan aturan prosedur dan standar baku yang telah ditetapkan

- Untuk melakukan kontrol terhadap top manajemen agar lebih terfokus dan konsisten dalam mencapai target capaian mutu yang telah ditetapkan.

ISO 9001:2015 telah secara resmi diluncurkan pada tanggal 23 September 2015 dengan memiliki 10 klausul sistem manajemen mutu. Klausul 1 hingga 3 merupakan pengantar dari ISO 9001:2015, sedangkan klausul 4 hingga 10 wajib untuk diterapkan pada sistem manajemen mutu dengan sertifikasi ISO 9001:2015.

\section{Audit Internal}

Audit internal adalah suatu fungsi penilaian yang dilakukan secara independen oleh organisasi untuk memeriksa dan mengevaluasi secara objektif aktivitas-aktivitas yang berada di dalam organisasi. Hasil dari audit internal dapat berupa saran, rekomendasi, analisis, dan saran yang dapat berguna bagi manajemen untuk 
meningkatkan performa perusahaan dan agar perusahaan dapat berjalan sesuai dengan tujuan yang telah ditetapkan (Rachmawati, 2018).

\section{Self assessment}

Self assessment atau penilaian secara mandiri adalah tindakan perencanaan yang dapat digunakan untuk mengetahui tingkat kemampuan diri sendiri dan perencanaan perbaikan yang akan dilakukan. Self assessment dapat digunakan untuk menyediakan dan mengakomodasi evaluasi kinerja dari organisasi sehingga organisasi dapat menganalisis dan membandingkan pencapaian tujuan, strategi dan tindakan yang telah diterapkan dan dilakukan oleh organisasi. Self assessment berfungsi untuk penerapan strategi dalam jangka panjang untuk mendorong adanya suatu perbaikan dan peningkatan yang berkelanjutan (Rahardjo, 2019). Self-assessment merupakan suatu cara yang dapat digunakan untuk mengidentifikasi informasi berupa kekuatan dan peluang yang dapat digunakan untuk strategi organisasi. Informasi tersebut dapat diketahui dengan menentukan dan mengukur indikator kinerja dari pelanggan, pasar, para staf/karyawan, dan pihak-pihak lain yang berkepentingan (Dioh, Arijanto, \& Nugraha, 2015).

\section{E. Metode Baldrige scoring}

Metode Baldrige Scoring adalah salah satu alat yang dapat digunakan untuk mengidentifikasi dan mengevaluasi kinerja dari sebuah organisasi atau unit-unit kerja. Metode Baldrige Scoring adalah salah satu metode yang digunakan untuk self-assessment. Terdapat empat faktor yang digunakan untuk mengevaluasi proses dalam metode Baldrige Scoring yaitu adalah ADLI (Approach, Deployment, Learning dan Integration). ADLI merupakan sebuah sistem penilaian yang digunakan untuk mengevaluasi sebuah proses. ADLI dapat dijabarkan sebagai berikut.

1. Approach: Approach atau pendekatan mengacu pada kesesuaian metode yang digunakan untuk menjalankan sebuah proses, kesesuaian metode dengan persyaratan yang telah ditetapkan dan lingkungan organisasi, efektifitas penggunaan metode, dan sejauh mana pendekatan yang dilakukan diambil berdasarkan data yang dapat diandalkan (reliable) dan dapat diulang.

2. Deployment: Deployment atau penyebarluasan mengacu pada pendekatan yang telah diterapkan secara konsisten oleh suatu organisasi, pendekatan yang telah dijalankan oleh semua unit kerja yang sesuai dan pendekatan yang diterapkan untuk memenuhi persyaratan sudah relevan bagi organisasi.

3. Learning: Learning atau pembelajaran mengacu pada penyempurnaan pendekatan yang digunakan dengan adanya peningkatan dan evaluasi, adanya dorongan untuk memunculkan terobosan baru dalam pendekatan melalui inovasi, dan adanya langkah penyempurnaan dan inovasi pada setiap pendekatan oleh organisasi atau unit kerja.

4. Integration: Integration atau integrasi mengacu pada pendekatan yang digunakan telah selaras dan harmonis dengan kebutuhan organisasi, adanya keselarasan dan harmonisasi dalam rencana, proses, informasi, keputusan tentang sumber daya, tindakan, hasil, dan analisis untuk mendukung tujuan kunci organisasi (Baldrige Scoring System, (n.d.).

\section{F. Penelitian Terdahulu Mengenai Baldrige Scoring}

Penelitian self-assessment dengan menggunakan Baldrige Scoring sebelumnya pernah dilakukan oleh Benedictus Rahardjo pada jurnalnya yang berjudul "Perancangan dan Implementasi Self Assessment Untuk Sertifikasi ISO 9001:2015 Menggunakan Metode Baldrige Scoring" (Rahardjo, 2019). Perbedaan jurnal tersebut dengan penelitian ini adalah jurnal tersebut membuat rancangan self-assessment dengan bentuk checklist dan score persentase sedangkan penelitian ini berbentuk pertanyaan dan jawaban berupa degradasi penilaian.

\section{METODOLOGI}

Terdapat 6 langkah sistematis dalam penelitian yang dilakukan oleh penulis di dalam membuat rancangan self assessment. Langkah penelitian tersebut sebagai berikut: 


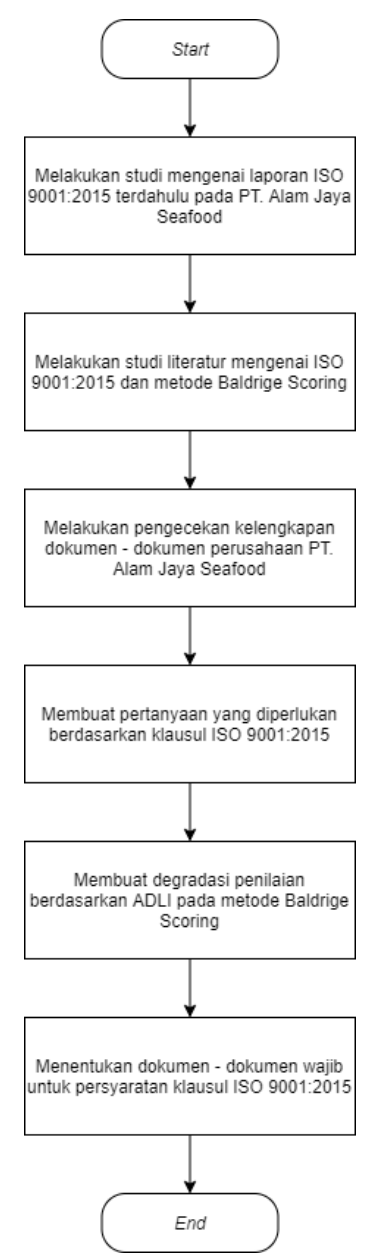

Gambar 1. Metodologi penelitian

1. Melakukan Studi Mengenai Laporan ISO 9001:2015 Terdahulu pada PT Alam Jaya Seafood Tahapan pertama yang dilakukan adalah melakukan studi literatur terhadap laporan tugas akhir milik Reynaldo Nyoto Widjojo dengan judul "Perancangan Sistem Manajemen Mutu ISO 9001:2015 pada PT Alam Jaya Seafood" dan penelitian Tugas Akhir milik Hendra Wijaya yang berjudul "Perancangan Pemenuhan Persyaratan Sertifikasi ISO 9001:2015 pada PT Alam Jaya Seafood". Studi ini dilakukan dengan tujuan untuk mengetahui sejauh mana penelitian terdahulu telah dilakukan.

2. Melakukan Studi Literatur Mengenai ISO 9001:2015 dan Metode Baldrige Scoring

Studi literatur mengenai ISO 9001:2015 dilakukan agar penulis dapat memahami secara mendalam mengenai ISO 9001:2015 beserta dengan klausul-klausul yang ada di dalamnya karena klausul akan menjadi dasar dari self assessment yang akan dibuat.

3. Melakukan Pengecekan Kelengkapan Dokumen-dokumen Perusahaan PT Alam Jaya Seafood

Pengecekan kelengkapan dokumen dilakukan untuk mengenal lebih dalam mengenai PT Alam Jaya Seafood dan untuk mengetahui sejauh mana PT Alam Jaya Seafood telah memenuhi kebutuhan administrasi yang diwajibkan untuk dapat memenuhi syarat ISO 9001:2015.

4. Membuat Pertanyaan yang Diperlukan Berdasarkan Klausul ISO 9001:2015

Pertanyaan dibuat berdasarkan nilai-nilai yang terdapat di dalam setiap klausul pada ISO 9001:2015. Pertanyaaan digunakan untuk menjadi dasar dari kriteria penilaian yang akan dilakukan pada self assessment ISO 9001:2015 pada PT Alam Jaya Seafood. Penilaian dilakukan dengan menjawab pertanyaan yang telah dibuat.

5. Membuat Degradasi Penilaian Berdasarkan ADLI pada Metode Baldrige scoring

Degradasi penilaian dibuat berdasarkan dengan empat faktor penilaian yang ada di dalam metode Baldrige scoring yaitu kriteria ADLI (Approach, Deployment, Learning dan Integration). Degradasi penilaian dibuat mengacu pada pertanyaan yang telah dibuat berdasarkan klausul ISO 9001:2015 pada tahap sebelumnya. Degradasi penilaian dibuat untuk mengetahui nilai dari kondisi perusahaan saat ini apakah berada pada tahap Approach, Deployment, Learning atau Integration. 
6. Menentukan Dokumen-dokumen Wajib untuk Persyaratan Klausul ISO 9001:2015

Dalam penilaian self assessment, perlu dipastikan bahwa setiap departemen terkait sudah memiliki dokumen wajib yang telah ditentukan di dalam klausul ISO 9001:2015. Jika belum memiliki, maka departemen tersebut perlu untuk melengkapi dokumen- dokumen yang kurang.

\section{HASIL DAN DISKUSI}

Rancangan self assessment dibuat dengan memperhatikan pada setiap klausul yang ada di dalam ISO 9001:2015 dari klausul 4 hingga klausul 10. Rancangan pertanyaan dibuat terlebih dahulu kemudian dilanjutkan dengan degradasi penilaian sesuai dengan metode penilaian Baldrige Scoring yaitu ADLI (Approach, Deployment, Learning, Integration).

Terdapat beberapa tahapan dalam perancangan self assessment. Tahapan awal yaitu membuat rancangan adalah dengan melakukan studi literatur mengenai laporan terdahulu, ISO 9001:2015 dan metode Baldrige Scoring. Pada penelitian ini digunakan metode Baldrige Scoring sebagai dasar degradasi penilaian karena Baldrige Scoring merupakan salah satu metode yang dapat digunakan untuk self assessment. Pada laporan terdahulu tersebut belum terdapat Audit internal yang menjadi persyaratan wajib dalam ISO 9001:2015.

Tahap selanjutnya adalah membuat pertanyaan berdasarkan isi dari sub-bab klausul yang terdapat pada ISO 9001:2015. Pertanyaan dibuat berdasarkan poin-poin penting dalam klausul yang harus dipenuhi oleh organisasi. Pertanyaan dibuat secara detail namun mudah untuk dipahami. Contoh dari pertanyaan pertama yang telah dibuat dari klausul 8.1 adalah "Apakah organisasi telah merencanakan, menerapkan, dan menentukan persyaratan untuk proses operasi produk frozen seafood yang diproduksi?".

Tahap selanjutnya adalah membuat degradasi penilaian. Degradasi penilaian ini berlaku untuk semua klausul ISO 9001:2015. Terdapat 5 kriteria penilaian yang digunakan seperti tabel berikut.

Tabel 1

Degradasi penilaian

\begin{tabular}{cccc}
\hline $\begin{array}{c}\text { Degradasi } \\
\text { Penilaian }\end{array}$ & Tahapan & Kriteria & Penjelasan \\
\hline 0 & $\begin{array}{c}\text { Tidak ada } \\
\text { pendekatan }\end{array}$ & $\begin{array}{c}\text { Sangat } \\
\text { kurang }\end{array}$ & $\begin{array}{c}\text { Tidak ada pendekatan sistematis yang dilakukan untuk memenuhi persyaratan } \\
\text { klausul }\end{array}$ \\
1 & Approach & Kurang & Pendekatan telah ditentukan namun belum diterapkan oleh perusahaan \\
2 & Deploy & Standar & Pendekatan telah diterapkan secara konsisten oleh perusahaan \\
3 & Learning & Baik & Perusahaan telah melakukan peningkatan dan penyempurnaan terhadap \\
pendekatan yang digunakan
\end{tabular}

Auditee dapat memberikan nilai dari pertanyaan sesuai dengan keadaan nyata yang terjadi di dalam organisasi pada kolom yang disediakan di samping kolom degradasi penilaian. Pertanyaan tersebut akan dijawab dengan degradasi penilaian. Contoh hasil degradasi penilaian yaitu penilaian dengan nilai 0 dari pertanyaan pertama pada klausul 8.1 adalah "Organisasi belum merencanakan, menerapkan dan menentukan persyaratan untuk proses operasi produk frozen seafood.". Penilaian dengan nilai 1 dari pertanyaan pertama pada klausul 8.1 adalah "Organisasi telah merencanakan, namun belum menerapkan dan menentukan persyaratan untuk proses operasi produk frozen seafood". Penilaian dengan nilai 2 dari pertanyaan pertama pada klausul 8.1 adalah "Organisasi telah merencanakan dan menerapkan namun belum menentukan persyaratan untuk proses operasi produk frozen seafood". Penilaian dengan nilai 3 dari pertanyaan pertama pada klausul 8.1 adalah "Organisasi telah merencanakan, menerapkan dan menentukan persyaratan untuk proses operasi produk frozen seafood" dan nilai ke 4 adalah "Organisasi telah merencanakan, menerapkan dan menentukan persyaratan untuk proses operasi produk frozen food dan dievaluasi secara berkala".

Tahap selanjutnya adalah membuat tabel dari dokumen-dokumen yang wajib dipenuhi oleh organisasi. Auditee harus memastikan bahwa organisasi memiliki dokumen tersebut untuk mendapatkan sertifikasi ISO 9001:2015. Jika dokumen wajib belum lengkap, maka departemen tersebut perlu untuk melengkapi dokumen- 
dokumen yang kurang. Contoh dari dokumen yang harus dipenuhi dari pertanyaan pertama pada klausul 8.4 adalah dokumen Hasil Pemantauan dan Evaluasi dari Penyedia Proses, Produk dan Jasa Eksternal. Berikut adalah contoh hasil keseluruhan rancangan self assessment pada klausul 8 yang membahas mengenai proses operasi di dalam suatu organisasi.

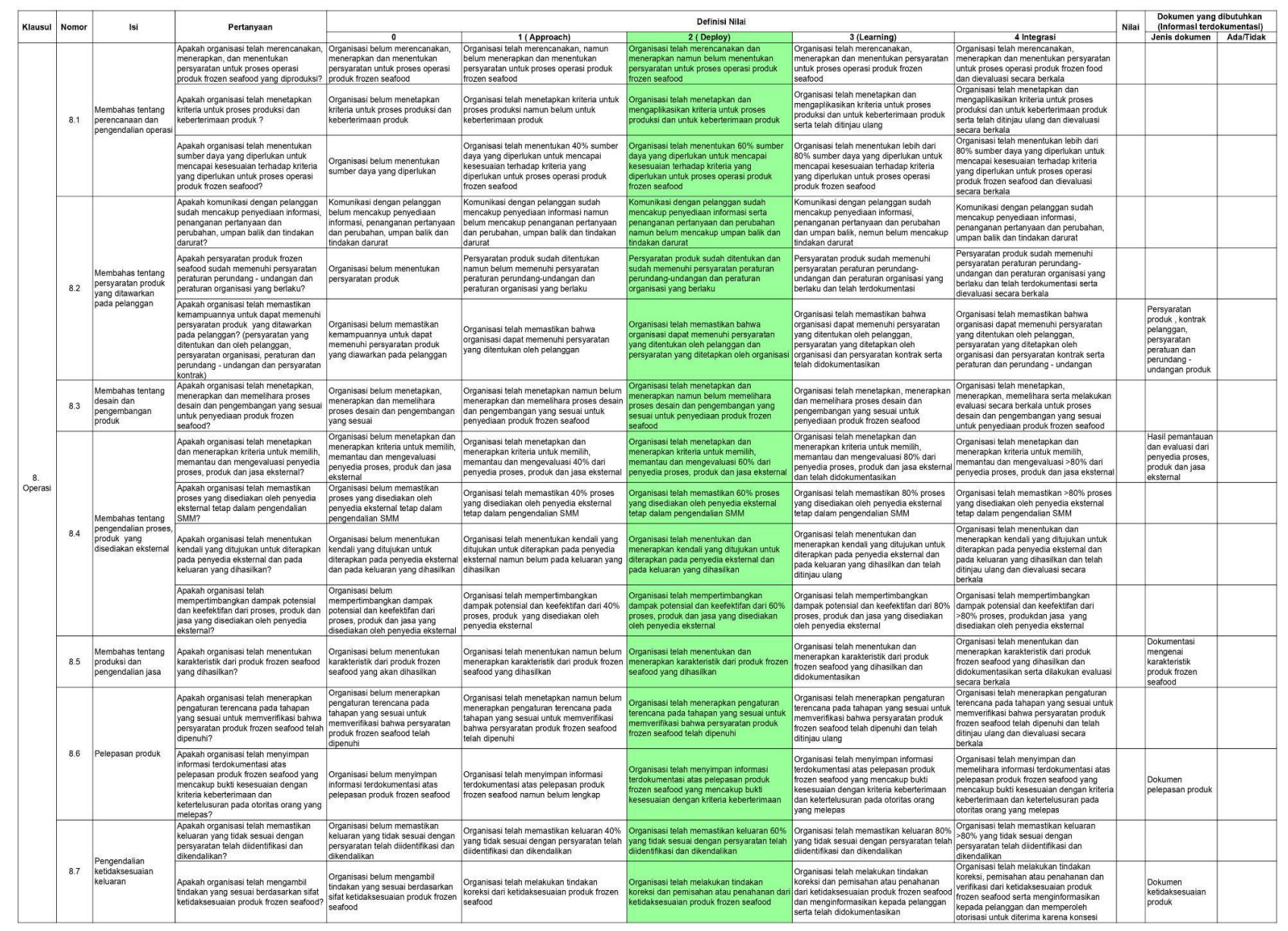

Gambar 2. Pertanyaan dan degradasi penilaian pada klausul 8

Berdasarkan Gambar 2, penilaian dengan rancangan self assessment akan dilakukan oleh seorang auditee yang berasal dari departemen selain departemen yang dinilai. Selanjutnya penilaian akan diverifikasi oleh auditor lain selain yang menilai. Hal tersebut dilakukan agar tidak dilakukan kecurangan oleh pihak yang bersangkutan dengan penilaian. Nilai 2 atau tahap deploy pada degradasi penilaian adalah nilai standar yang harus dipenuhi oleh organisasi, sedangkan nilai 0 dan 1 dinilai kurang, 3 dan 4 dinilai bagus atau excellent. Perusahaan dapat melakukan perbaikan untuk meningkatkan sistem manajemen mutu dengan cara memenuhi persyaratan yang terdapat pada degradasi penilaian hingga mencapai nilai 4.

\section{KESIMPULAN}

Audit internal merupakan salah satu syarat yang wajib dipenuhi untuk memperoleh sertifikasi ISO 9001:2015. Audit internal dapat dilakukan secara mandiri atau disebut self-assessment dengan menggunakan kriteria penilaian ADLI dengan metode Baldrige Scoring. Self Assessment dilakukan oleh masing - masing departemen dari perusahaan yang kemudian akan diverifikasi oleh auditor yang dipilih dari perusahaan. Hasil penilaian self assessment menunjukkan kondisi nilai nyata dari perusahaan dengan nilai 2 sebagai nilai standar untuk memperoleh sertifikasi ISO 9001:2015. Rancangan self assessment dapat membantu perusahaan untuk melakukan langkah-langkah perbaikan demi menciptakan peningkatan sistem manajemen mutu dengan mengacu pada kriteria persyaratan yang tertera pada degradasi penilaian self assessment. Self assessment diharapkan untuk dapat mendukung pelaksanaan audit internal yang diperlukan sebagai syarat wajib untuk 
memperoleh ISO 9001:2015 di PT Alam Jaya Seafood. Dengan adanya sertifikasi ISO 9001:2015 di PT Alam Jaya Seafood diharapkan mampu memberikan jaminan mutu terhadap produk PT Alam Jaya Seafood sehingga dapat memberikan dan meningkatkan kepercayaan dan kepuasan bagi konsumen.

\section{DAFTAR PUSTAKA}

Badan Standarisasi Internasional. (2015). Sistem manajemen mutu - Persyaratan. Badan Standarisasi Internasional

$\begin{array}{lllll}\text { Baldrige Scoring System. } & \text { (n.d.). } & \text { Retrieved }\end{array}$ http://www.baldrige21.com/Baldrige\%20Scoring\%20System.html

Dioh, D., Arijanto, S., \& Nugraha, C. (2015). Sistem Perangkat Lunak untuk Internal Assessment Malcolm Baldrige for Performance Excellence (Kategori 6 - Fokus Operasi) Berbasis Pengukuran KPU - BUMN. Jurnal Online Institut Teknologi Nasional, 3 (3).

Eric,E. (2020). Perancangan Sistem Manajemen Mutu ISO 9001:2015 di PT. Carkratek.(Thesis).Universitas Kristen Petra. Retrieved from https://dewey.petra.ac.id/catalog/digital/preview?id=2192110

Gaspersz, V. (2002). ISO 9001:2000 and continual quality improvement. Jakarta: PT. Gramedia Pustaka Utama.

Kurniawan,R. (2018). Perancangan Analisis Risiko Sistem Manajemen Mutu ISO 9001:2015 di PT. $\begin{array}{llll}X .(T h e s i s) . U n i v e r s i t a s & \text { Kristen } & \text { Petra. } & \text { Retrieved }\end{array}$ https://dewey.petra.ac.id/catalog/digital/preview?id=2145667.

Nasikin,A.I.(2019). Analisa Gap pada Penerapan Sistem Manajemen Mutu ISO 9001:2015 pada PT. X. (Thesis). Universitas Kristen Petra. Retrieved https://dewey.petra.ac.id/catalog/digital/preview?id=2152066

Rachmawati, Ratih. (2018). Peran Audit Internal Pada Efektivitas Pengendalian Internal Mendukung Kredit Investasi Di Cabang BRI Di Situbondo. Jurnal Relasi, 14 (2), 29-30.

Rahardjo, B. (2019). Perancangan dan Implementasi Self Assessment Untuk Sertifikasi ISO 9001:2015. Jurnal Media Teknik \& Sistem Industri, 3 (1), 2-3.

Pengertian ISO 9001:2015. (2020, February 25). Retrieved from https://gsmcertification.com/pengertian-iso90012015/ 